\title{
CHANGES OF HYDROGRAPHIC NETWORK OF UŚCIWIERSKIE LOWERING ACCORDING TO CARTOGRAFIC MATERIALS
}

\author{
Antoni Grzywna' ${ }^{1}, K^{2}$ il Nieścioruk ${ }^{1}$ \\ 1 Department of Environmental Engineering and Geodesy. University of Live Sciences in Lublin, Leszczyń- \\ skiego 7, 20-069 Lublin, Poland, e-mail: antoni.grzywna@up.lublin.pl
}

Received: 2016.07.01

Accepted: 2016.08 .17

Published: 2016.09.30

\begin{abstract}
The paper analyses a hydrographic network and its changes in the area of Uściwierskie Lowering in last 180 years. The Uściwierskie Lowering was originally the second largest closed drainage depression in Łęczna-Włodawa Lakeland, with an area of $45.83 \mathrm{~km}^{2}$. The increasing anthropopression mainly by melioration works led to significant changes. The authors use early and modern maps to analyse the quantitative aspect of these changes. The technical issues of georeferencing maps in the Geographic Information System (GIS) software are addressed first. In case of some maps, georectification happened to be problematic. $19^{\text {th }}$ century topographic maps (as the Quartermaster map) were of much lower geometric quality compared to early $20^{\text {th }}$ century and modern maps. Also the poor settlement in the area resulted in lack of ground control points useful in case of georectification. Using such data can, however, be justified by the fact that little is known about changes in the hydrographic network of the region during the $19^{\text {th }}$ century, while the period of last $50-100$ years is examined with more details. The results show the numeric values illustrating quantitative changes in the area. They are also a step forward towards understanding the degree of anthropogenic transformation of a drainage network. It is vital as these changes influence the whole ecosystem - lowering the water level shapes habitats and change the landscape.
\end{abstract}

Keywords: lakes, river, ditches, early maps, drainage

\section{INTRODUCTION}

Within the last centuries the ŁęcznaWłodawa Lakeland has been a subject to systematic, continuously intensifying anthropopression [Chmielewski and Radwan 1993]. One of its symptoms is the development of drainage systems, leading to the incorporation of lakes into a drainage network [Wilgat et al. 1991]. As a result of these processes, the character of lakes changed from closed- to open-drainage and a decrease in the water level and reduction of maximum extent was, and still is, observed. Although natural processes also lead to the development of a drainage network, the human melioration practices substantially accelerate the process. Moreover, a change in the character of a lake from closed- to open-drainage or flow-through by its incorpora- tion in the drainage system results in a number of not only hydrological, but consequently also hydrobiological changes.

In the Lęczna-Włodawa Lakeland, melioration activities were conducted with high intensity after the Second World War, as an access to many settlements in the melting season was still very difficult. The most intensive works have been carried out since 1954, in connection with the construction of the Wieprz-Krzna Canal, completed in 1961 [Michalczyk 1994]. Meliorations resulted in an increased runoff of surface waters and a decrease in the level of groundwater, as well as in transformation of peatlands into muck (Michalczyk 2009). In the period of 1952-1992, 5 out of 68 lakes existing in the lakeland disappeared completely [Chmielewski and Chmielewski 2009]. 
While changes in the drainage system in the area of Łęczna-Włodawa Lakeland within the last 50-100 years are thoroughly studied [Chmielewski and Radwan 1993; Michalczyk 1994, Michalczyk 2009], much less is known on changes occurring before that. Early maps can be of significant help in case of analysing spatiotemporal changes. The oldest cartographic source studied by authors is the Quartermaster Map, presenting the situation from the 1839 [Dawidek and Turczyński 2007]. Another, direct (comparing to use of early maps), source of information on the functioning of the lakes and wetlands of the Łęczna-Włodawa Lakeland is palaeogeographical studies [Kulesza et al. 2012]. Much less attention was paid to high-resolution analyses regarding the last centuries [Kaczorowska and Kornijów 2012; Kowalewski 2012].

The objective of the study is to analyse an extent of environmental hydrographic changes of Uściwierskie Lowering based on the archival, early topographic maps. The analysis includes the measurements of the surface of lakes and the length of watercourses in the period of 1839-2011.

\section{MATERIALS AND METHOD}

The Uściwierskie Lowering was originally the second largest (after Krowie Bagno wetland) closed drainage depression, with the area of 45.83 $\mathrm{km}^{2}$. Closed-drainage areas originally occupied $43 \%$ of the Lęczna-Włodawa Lakeland. Human activity resulted in dissecting the natural watersheds and drainage of the internal part of the lakeland, with its waters discharged to the Bug and Tyśmienica Rivers. The percentage of closeddrainage areas determines the unique character of the lakeland. In the old glaciation zone, closeddrainage areas occupied $2 \%$ of its area, and in the young glaciation zone $12-16 \%$ [Kowalewski et al. 2013]. The Lowering was originally filled with waters of probably a single lake with a number of islands and a fragmented shoreline. It is currently filled with limnic sediments and peats [Okruszko et al. 1971]. Only in the deepest (>10 m) parts of the original lake basin, shallow lakes still exist, usually surrounded by rushes and floating plants [Sposób and Turczyński 2009]. On the southern side, the Uściwierskie Lowering is closed by the Garbatówka Hump, composed of marls and Upper Cretaceous limestone, locally covered with sands and silts. The incorporation of the Lowering into the drainage network resulted in the development of the Piwonia Dolna Stream. A part of the Lowering is located within the range of activity of the mining area of the "Bogdanka" coal mine. The most substantial anthropogenic transformations in the Lowering occurred in the years 1950-1990, and led to considerable degradation of the area [Chmielewski and Radwan 1993, Łoś 1997, Michalczyk et al. 2007].

The research uses the following maps: Topograficzna Karta Królestwa Polskiego (so-called Quartermaster Map) 1:126,000 (sheet VI-IX, published in 1943 with topographic situation as recent as 1839), Karte des Westlichen Ruslands 1:100,000 (sheet M36 Lenczna (sic!), published in 1914), Tactical map of Military Geographical Institute (WIG) 1:100,000 (sheet P43 S36 Łęczna, published in 1938), System 1965 ("Układ 1965" in Polish) 1:50,000 map (sheet 136.2 Puchaczów, with situation dated by to 1967 in the analysed area and the visualization of vector VMap Level2 accessed via Polish Geoportal. The maps were georectified using ArcMap (version 10.2) of ArcGIS software package. Due to the problematic projection and reference systems of these maps, they were registered mainly using topographic features, not the topographic graticule. Both WIG and Karte des Westilichen Russlands can be treated as modern 20th century topographic maps, so they mathematic basis are quite good. The georeferencing process in case of them produces a reliable material. The Quartermaster map is a bit different case. This mid-19th century map is not as good in terms of geometric accuracy as the previous two were. Beside this, in areas of poor settlement network, like analysed Polesie region, it is hard to identify topographic features that could be used as stable reference points.

\section{RESULTS}

The determination of the time of beginning of transformations of the drainage network of the Łęczna-Włodawa Lakeland, and particularly the originally closed-drainage Uściwierskie Lowering, is a problematic issue due to the scarcity of sources. The issue of anthropogenic transformations of the Uściwierskie Lowering has been discussed in other papers, including the pioneer works by Wilgat [1954], addressing the issue of closed-drainage areas numerous in the Lęczna- 
Włodawa Lakeland among other topics. Sposób and Turczyński [2009], as well as Michalczyk [1994] set the beginning of melioration works to the 18th century. Suchożebrska and Chabudziński [2007] determine only slight transformations of the drainage system of the Lowering according to the 1839 map. The hydrographical situation presented there had not been transformed by man in any significant way. A single ditch draining the north-eastern part and infringing its natural borders was in the Uściwierz catchment only (Fig. 1). The draining elements of the Lowering around 1830 were unnoted in Sposób and Turczyński (2009) also. The length of the ditches in the early 19th century was only 8.2 kilometres (Table 2).

The analysis of water level fluctuations, based on changes in the lake's surface area is not very precise, especially that in the case of the lakes of the Uściwierskie Lowering, the determination of the surface area of the lake is problematic [Sposób and Turczyński 2009]. The total area of lakes on the map from 1914 was 593 ha, while the length of watercourses was $29.6 \mathrm{~km}$ (Table 1 and 2). The Piwonia river had its beginning from the lake Nadrybie and flew through the Lake Bikcze then (Fig. 2). Significant changes to the Uściwierskie Lowering drainage system were observed between the First and Second World War. During this period, the surface of lakes decreased by 34 ha, while the length of watercourses increased by $7.9 \mathrm{~km}$. The water level in Lake Rotcze could have begun to decrease along with the develop- ment of a drainage system to the west of the lake between 1918 and 1936, documented with the WIG map 1:100000 (Fig. 3). This could be related to the plans of the owner of Lake Rotcze and the heir of Garbatówka. In the 1920's, he was going to develop fish farming in Lakes Rotcze and Uścimowskie, but as a result of the economic crisis, the lake was taken over by a bank. After the 2nd World War, significant changes were caused by the construction of the irrigation ditch Bogdanka-Wola Wereszczyńska in the 1950s, running along the northern shore of the lake and being usually empty. The fastest decrease of water level has probably happened after 1963 . There were transformation planned aiming at the improvement of habitat conditions, with the purpose of transforming Lakes Uściwierz, Nadrybie, and Bikcze into retention reservoirs. The plan was not successful, but surrounding wetlands were irreversibly changed. The then-constructed Wola Wereszczyńska-Bogdanka irrigation canal is defunct now and the water level in the surrounding lakes decreased by approximately one meter.

The level of Lake Uściwierz, drained already before 1804, decreased to a lesser extent, but part of the decrease occurred in the second half of the 20th century, as indirectly documented by Chmielewski and Chmielewski [2009]. The surface area of Lake Uściwierz according to the cited authors decreased in the years $1952-2007$ by approximately $8 \%$, and the area of the open water by approximately $27 \%$. The problem of the water

Table 1. Water surface areas of lakes [ha]

\begin{tabular}{|l|c|c|c|c|c|}
\hline \multicolumn{1}{|c|}{ Lake } & 1838 & 1914 & 1938 & 1967 & 2011 \\
\hline Bikcze & 86 & 88 & 82 & 77 & 69 \\
\hline Nadrybie & 48 & 55 & 48 & 44 & 40 \\
\hline Uściwierz & 251 & 280 & 273 & 265 & 255 \\
\hline Uściwierzek & 17 & 9 & 8 & 7 & 7 \\
\hline Ciesacin & 4 & 8 & 0 & 0 & 0 \\
\hline Rotcze & 40 & 47 & 45 & 46 & 40 \\
\hline Sumin & 92 & 106 & 108 & 84 & 80 \\
\hline Total & 538 & 593 & 564 & 523 & 491 \\
\hline
\end{tabular}

Table 2. Length of watercourses in the catchment area [m]

\begin{tabular}{|l|c|c|c|c|c|}
\hline \multicolumn{1}{|c|}{ Basin } & 1838 & 1914 & 1938 & 1967 & 2011 \\
\hline Wieprz & 6279 & 25317 & 21065 & 55820 & 54140 \\
\hline Bug & 1905 & 4304 & 16463 & 12750 & 21370 \\
\hline Total & 8184 & 29621 & 37528 & 68570 & 75510 \\
\hline
\end{tabular}




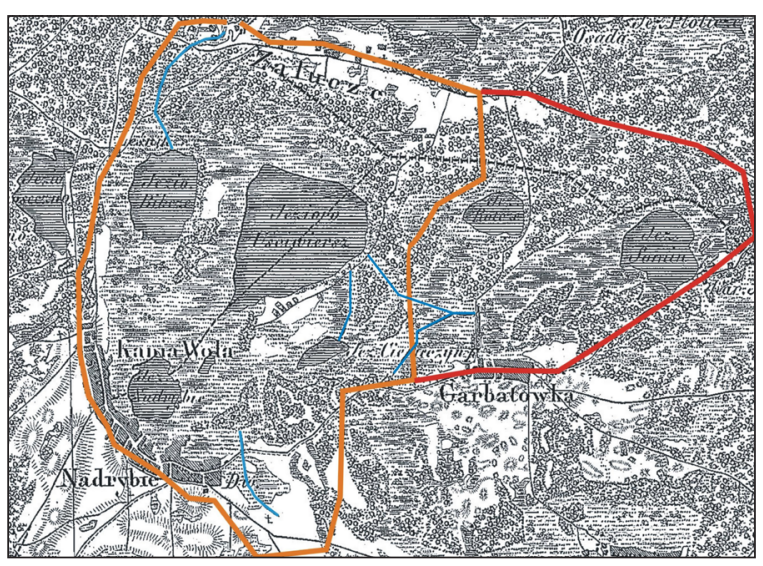

Figure 1. Quartermaster Map from 1839 Wieprz basin, Bug basin

levels was not investigated in the mentioned research, however. While for 2007 the level of the surface elevated to an average of 169.5 m.a.s.l. for Lake Uściwierz [Michalczyk et al. 2011], the value for 1952 is unknown. In spite of this fact, phenomena like e.g. disappearance of numerous peatland areas and an increase in forest areas unequivocally suggest a decrease in the water level in the lakes of the Uściwierskie Lowering.

A decrease in the water level in the Uściwierskie Lowering after the 1950s is also confirmed by records of the nearby piezometer in Ludwin, recorded from 1951, indicating levels over $0.5 \mathrm{~m}$ higher during the entire decade of the 1950s comparing to the following years (Michalczyk 1994). It can also be used to evaluate the results of draining, conducted with a particular intensity from the mid-20th century. According to Wilgat et al. [1991] man has influenced the drainage network for a long time, mainly by regulating

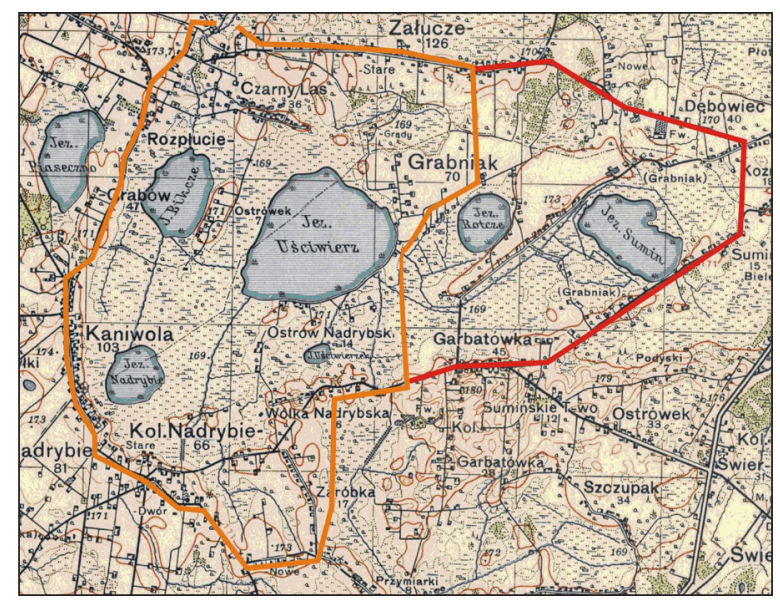

Figure 3. Map of the Military Geographical Institute (WIG), 1938

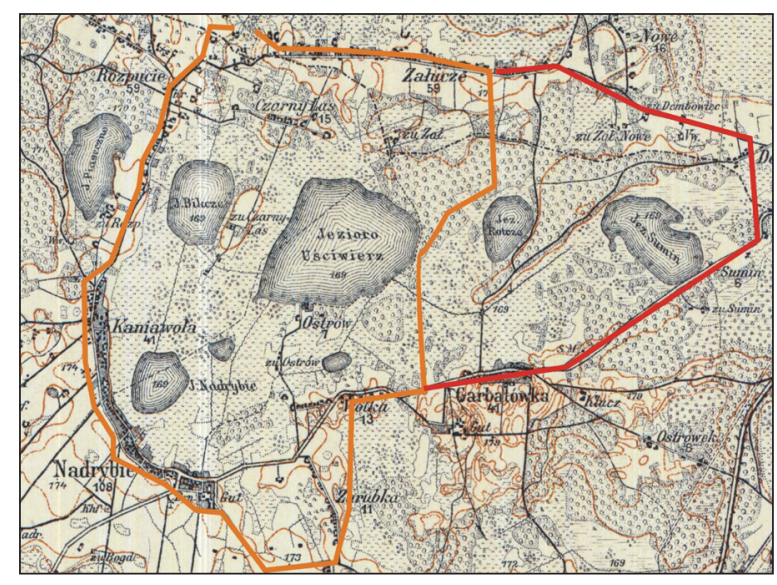

Figure 2. Karte des Westlichen Ruslands, 1914

river channels and digging ditches to drain excess water, which in a flat, sandy area was not difficult, and by the incorporating lakes and closeddrainage depressions into the drainage network. All this was evident, but did not significantly affect the character of drainage network. Significant changes are related to the construction of the melioration system of the Wieprz-Krzna Canal [Harasimiuk et al. 1998]. The construction of agricultural drainage systems resulted in a decrease in the groundwater level in a number of places, drying wetland areas. It also caused an acceleration of the spring runoff (Fig. 4).

The most intense hydrotechnical works were carried out in the 1960's. At that time headwaters of the river Piwonia were moved to the lake Uściwierzek, while its bed was traced to pass the lakes Nadrybie and Bikcze. After the Second World War the area of lakes decreased by 36 ha, and the length of the courses increased by $31 \mathrm{~km}$

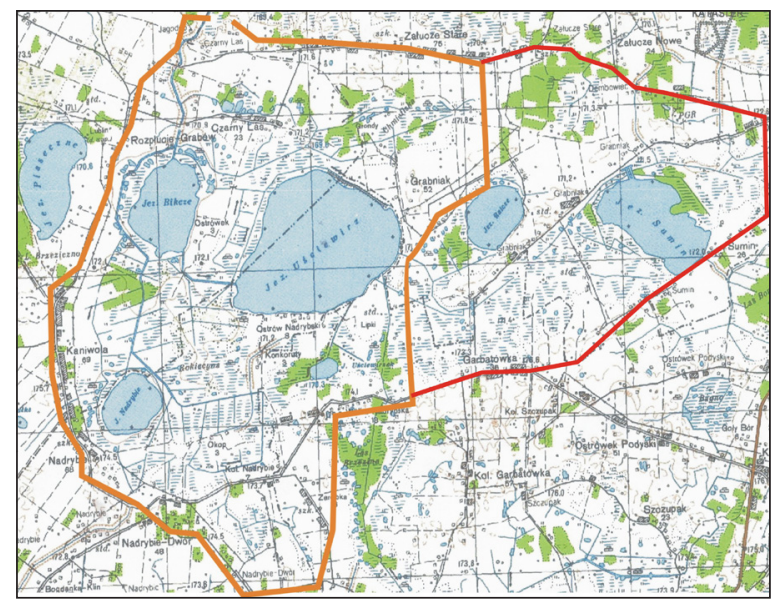

Figure 4. System 1965 topographic map, 1967 
(Table 1 and 2). Zones not connected to the Canal have their own drainage systems, some of which were constructed a long time ago and restored in the recent years, while some were developed from scratch. It seems, however, that the occurrence of significant changes in the drainage system after the Second World War concerns, in the case of the Uściwierskie Lowering, Lake Rotcze solely. The rest of lakes were already a subject to transformations in 19th century.

The total area of lakes in the past 40 years decreased by 32 ha, while the length of watercourses increased by $7 \mathrm{~km}$ (Table 1 and 2). There are only artificial watercourses in the Lowering today: drainage ditch, Bogdanka-Wola Wereszczyńska Canal and Canal of Piwonia Dolna river (Fig. 5).

The values given in tables and based on maps are true, but a few things have to be noted. The first one is the content of the map. There is no single, unique instruction how to delimit lake on a map. In most cases it is obvious, but on areas of wetland a shoreline can be more of a zone than a precise line. The quantitative information, that is a second thing to note, is a matter of scale of course, hence maps of similar scale should be compared. But even in such case the differences observed (for example lake areas) may be a result of different approach of the cartographer and different technical instruction of the map. The third, and probably the most important note here, is the reliability of georectification. In general, the older the map is, the less reliable it is in terms of geometric accuracy and its georectification can be less precise. However, when a series of map are well-georeferenced, they can give not a very pre-

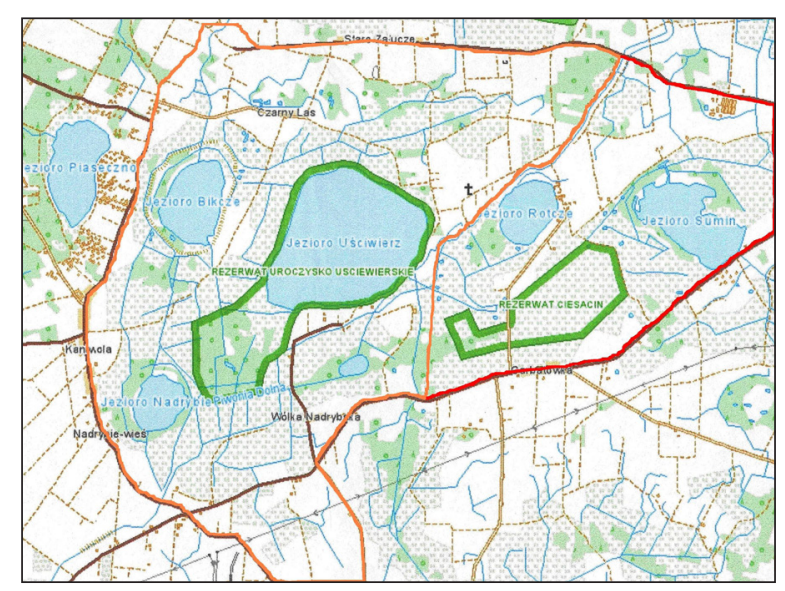

Figure 5. Visualisation of VMap L2 topographic database, 2011 cise absolute values, but relative values (one compared to another) can be of much higher quality.

\section{CONCLUSIONS}

1. Drainage of lakes by means of drainage ditches led to lowering of lakes level and, consequently, decrease of their surface areas. The lowering also caused faster development of rush vegetation and macrophytes in the lakes' basins, accelerating the disappearance of the lake. Decreases in the water level occurred in an uneven manner. The earliest changes concerned the water level in Lake Bikcze which - after digging a ditch draining the lake to the north stabilised at the beginning of the 19th century.

2. In order to understand the degree of anthropogenic transformations of the drainage network, knowledge on its natural changes is required. Therefore, the reconstruction of water level fluctuations in Polesie within the last 200-500 years is urgently required, particularly involving palaeolimnological and telmatological studies and studies of historical sources recording at least extreme facts. Only then it is possible to fully analyse anthropogenic changes. In order to estimate water level fluctuations based on aerial photographs and cartographic sources, knowledge on the water level in the observation period is required. This was emphasised by, among others, Chmielewski and Radwan [1993], Dawidek and Turczyński [2007], as well as Harasimiuk et al. [1998]. The knowledge is necessary for the accurate interpretation of changes in the lakes' water level, surface area and volume.

3. While changes in the drainage system occurring in the Łęczna-Włodawa Lakeland within the last 50-100 years are thoroughly studied [Chmielewski and Radwan 1993; Michalczyk 2009, Łoś 1997], much less is known on changes occurring before. The oldest cartographic source consulted by authors is the Quartermaster Map, presenting the situation from the 1830s [Dawidek and Turczyński 2007], but its geometric quality is not as good as in case of more modern maps.

4. In 100 years area of lakes decreased from 593 to 491 hectares, and the length of watercourses has increased from 29.6 to $75.5 \mathrm{~km}$. 


\section{REFERENCES}

1. Chmielewski J.T., Radwan S. 1993. Changes in ecological relations in Polesie National Park during the last 75 years. [In:] Radwan S., Karbowski Z., Sołtys M. (eds). Freshwater and peat-bog ecosystems in protected areas. TWWP, Lublin: 13-25 (in Polish).

2. Chmielewski Sz., Chmielewski T. J., 2009. Analysis of land use structure changes in the years 1952-2007; [in:] Chmielewski T.J. (ed.), Ecology of hydrogenic landscapes of the "West Polesie" Biosphere Reserve , Wyd. PZN, Lublin: 47-70 (in Polish).

3. Dawidek J., Turczyński M., 2007. Former topographic maps of the Lublin region in surveys of changes in water conditions); [in:] Michalczyk Z. (ed.) Water circulation in natural and transformed environment. 175-184 (in Polish).

4. Harasimiuk M., Michalczyk Z., Turczyński M. (eds), 1998. Jeziora łęczyńsko-włodawskie. Monografia przyrodnicza. Biblioteka Monitoringu Środowiska, Wyd. UMCS, Lublin, p. 176.

5. Kaczorowska A., Kornijów R., 2012. Palaeoecological evidence for changes over the past 200 years in chironomid communities of a shallow lake exposed to cyanobacterial toxins. Aquatic Ecology 46: 465-473.

6. Kowalewski G.A., Kornijów R., McGowan S., Woszczyk M., Suchora M., Bałaga K., Kaczorowska A., Gąsiorowski M., Szeroczyńska K., Wasiłowska A., 2013. Persistence of protected, vulnerable macrophyte species in a small, shallow eutrophic lake (eastern Poland) over the past two centuries: Implications for lake management and conservation. Aquatic Botany 106: 1-13. http:// dx.doi.org/10.1016/j.aquabot.

7. Kowalewski. G., 2012. Over 200 years of drainage practices and lake level drawdown in the Uściwierskie Lowering (Lęczna-Włodawa Lakeland). Limnological Review. 12, 4: 179-190.

8. Kulesza P., Suchora M., Pidek I.A., Dobrowolski R., Alexandrowicz W.P., 2012. The Holocene palaeoenvironmental changes reflected in the multiproxy studies of Lake Słone sediments (SE Poland). Palaeogeography, Palaeoclimatology. 363, 79-98.
9. Łoś M. J., 1997. The impact of the Canal WieprzKrzna on agriculture and the natural environment. Gospodarka Wodna, 56, 2, 59-61 (in Polish).

10. Michalczyk Z., 1994. Changes in the hydrographic network in the zone of impact of the Wieprz-Krzna Canal. [In:] Radwan S. (ed.) The natural environment in the zone of impact of the Wieprz-Krzna Canal. TWWP Lublin; 43-46 (in Polish).

11. Michalczyk Z., 2009. Problems of water conditions protection and the environmental monitoring in the Łęczna-Włodawa Lakeland. [In:] Chmielewski T.J., Sławiński C. (eds) Nature and Landscape monitoring system in the West Polesie Region, Wyd. PZN, Lublin: 152-159.

12. Michalczyk, Z. Chmiel, S. Chmielewski, J. Turczyński, M., 2007. Hydrological consequences of hard coal mining in the area of Bogdanka (LCB). Biuletyn Państwowego Instytutu Geologicznego 422: 113-125 (in Polish).

13. Michalczyk Z., Chmiel S., Turczyński M., 2011. Lake water stage dynamics in the Łęczna-Włodawa Lake District in 1991-2010. Limnological Review. 11, 3: 113-122.

14. Okruszko H., Churski T., Karpińska J., 1971. Peat and gyttja bogs in the region of Uściwierz karst lakes in Łęczna-Włodawa Lake District). Zesz. Probl. Post. Nauk Rol. 107: 121-165 (in Polish).

15. Sposób J., Turczyński M., 2009. Transformations of undrained areas into catchments of imposed water circulation: Łęczna-Włodawa Lake District. [In:] Bogdanowicz R., Fac-Beneda J. (eds). Water resources and water protection. Water and matter cycling in river Bains. FRUG, Gdańsk: 111-121 (in Polish, English summary).

16. Suchożebrska M., Chabudziński Ł., 2007. Anthropogenic Transformations of the Hydrographical Network in Lake Catchment Areas of the Uściwierz Lowering (Łęczna Włodawa Lake District). Limnological Review 7: 225-231.

17. Wilgat T., 1954. The Łęczna-Włodawa lakes. Ann. UMCS B, 8(3): 37-121 (in Polish).

18. Wilgat T., Michalczyk Z., Turczyński M., Wojciechowski K., 1991. Łęczna Włodawa Lake District. Studia Ośrodka Dokumentacji Fizjograficznyczej PAN 19, 23-140.

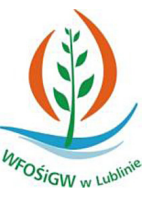

Pracę dofinansowano ze środków Wojewódzkiego Funduszu Ochrony Środowiska i Gospodarki Wodnej w Lublinie. 